\title{
ESSENTIAL OIL EXTRACTION INDUSTRY: EXPLORING THE STRATEGIC TECHNOLOGY DIMENSION
}

\author{
Carlos Alberto Tosta Machadora, Herman Augusto Lepikson ${ }^{b}$, Matheus Antônio \\ Nogueira de Andrade c, Yasmim Thasla Santos Ferreira ${ }^{d}$, Sara Freitas Santos \\ Vasconcelose
}

a Senai Cimatec University Center, Orlando Gomes Avenue, 1845 - Piatã, Salvador, BA, 41650-010, Brazil, carlos.tosta@uol.com.br

b Senai Cimatec University Center, Orlando Gomes Avenue, 1845 - Piatã, Salvador, BA, 41650-010, Brazil, herman.lepikson@fieb.org.br

- Universidade Federal da Bahia, Av. Adhemar de Barros, s/no - Ondina, Salvador BA, 40170-110, Brazil, matheus.andrade.Ip@gmail.com

a Senai Cimatec University Center, Orlando Gomes Avenue, 1845 - Piatã, Salvador, BA, 41650-010, Brazil, yasmim.thasla@gmail.com

- Senai Cimatec University Center, Orlando Gomes Avenue, 1845 - Piatã, Salvador, BA, 41650-010, Brazil, sarasantoos500@gmail.com

\begin{abstract}
This paper aims at the potential and unexplored improvements imbedded in the essential oil (EO) extraction processes. These processes are worldwide recognized by their low yields and high energy demands, becoming a target to be addressed to improve cost, reliability and quality indicators. A strategic thinking is presented, as a guide, with focus on enabling better business results through the TDC (Total Delivered Cost) optimization and the impact over gross margin in this promising segment. A basic process was evaluated, step by step, to then add technology improvements. The resulting impacts were assessed, improving yield from $1 \%$ to $1.2 \%$. Such improvements are discussed in terms of digital technology contribution with the expected positive effects.
\end{abstract}

Keywords: Essential Oils; technology; cost; strategy.

\section{EXTRAÇÃO DE ÓLEOS ESSENCIAIS: EXPLORANDO A DIMENSÃO TECNOLÓGICO-ESTRATÉGICA DO NEGÓCIO}

Resumo: Este artigo aborda as melhorias potenciais e inexploradas cabíveis aos processos de extração de óleos essenciais (OE). Esses processos são globalmente reconhecidos por seus baixos rendimentos e altas demandas de energia, tornando-se uma meta a ser trabalhada para melhorar os indicadores de custo, confiabilidade e qualidade. É apresentado um pensamento estratégico, a título de orientação, com foco em viabilizar resultados promissores de negócios, por meio da otimização do indicador TDC (Total Delivered Cost), custo total do produto entregue, e do impacto sobre a margem bruta, neste promissor segmento de negócios. Um processo básico foi avaliado, passo a passo, para então adicionar aprimoramentos de tecnologia. Os impactos resultantes foram avaliados, melhorando o rendimento apenas de $1 \%$ para $1,2 \%$. Essas melhorias são discutidas em termos de contribuição da tecnologia digital e seus efeitos positivos esperados.

Palavras-chave: Óleos Essenciais; tecnologia; custo; estratégia 


\section{INTRODUCTION}

Essential oils (EO) are aromatic liquid and volatile substances obtained through extraction processes from vegetal mass in several forms: flowers, leaves, roots, barks, fruits and seeds. The International Organization for Standardization (ISO 9235: 2013) defines them as "natural products obtained from vegetable raw materials [...] through physical processes". Approximately 3000 thousand types are known and, of these, approximately 300 are used in fragrances, food essences, cosmetics, pharmaceuticals, food and beverages [1], aromatherapy, preservatives and pesticides. The Commission of the European Pharmacopoeia has adopted the following definition: "Odorous product, usually with a complex composition, obtained from a botanically defined plant raw material by steam distillation, dry distillation, or a suitable mechanical process without heating".

\subsection{Methods of Extraction: Focus on Steam Distillation}

Among the several methods of essential oil extraction [2,3], named below in Table 1, this paper focus on the steam distillation due to the broad utilization worldwide [4], being responsible for $93 \%$ of the produced volume worldwide. The table also mentions the media where the extraction takes place as well as provides a perspective on the advantages and disadvantages for each method.

Table 1. Essential Oils methods of extraction

\begin{tabular}{|c|c|c|c|}
\hline Extraction Method & Extraction Media & Advantages & Disadvantages \\
\hline $\begin{array}{l}\text { Hydro-distillation; Vapor- } \\
\text { hydro-distillation; Steam } \\
\text { Distillation; Hydro- } \\
\text { diffusion }\end{array}$ & $\begin{array}{l}\text { Boiling water; } \\
\text { Steam }\end{array}$ & $\begin{array}{l}\text { Simplicity, relative low } \\
\text { investment. }\end{array}$ & $\begin{array}{c}\text { Prolonged process time; } \\
\text { possible degradation of } \\
\text { components }\end{array}$ \\
\hline Organic Solvent Extraction & $\begin{array}{l}\text { Maceration in } \\
\text { organic solvents }\end{array}$ & $\begin{array}{l}\text { Avoids chemical } \\
\text { degradation }\end{array}$ & $\begin{array}{l}\text { Possible residues of } \\
\text { solvents; Dangerous } \\
\text { waste; Flammability }\end{array}$ \\
\hline Cold Pressing & $\begin{array}{l}\text { Mechanical } \\
\text { pressing }\end{array}$ & Simplicity, Specificity & $\begin{array}{l}\text { Application restrictions } \\
\text { (citrus mainly) }\end{array}$ \\
\hline $\begin{array}{l}\text { Supercritical Fluid } \\
\text { Extraction - SCFE (Carbon } \\
\text { Dioxide generally applied) }\end{array}$ & $\begin{array}{l}\text { Supercritical Fluid } \\
\text { (Carbon Dioxide, } \\
\text { generally) }\end{array}$ & $\begin{array}{l}\text { Fluid is inert, non-toxic, } \\
\text { non-flammable }\end{array}$ & $\begin{array}{l}\text { High investment; high } \\
\text { maintenance costs }\end{array}$ \\
\hline $\begin{array}{l}\text { Subcritical liquids (Water } \\
\text { and Carbon Dioxide) }\end{array}$ & $\begin{array}{l}\text { Subcritical water or } \\
\text { CO2 }\end{array}$ & $\begin{array}{c}\text { Fluid is inert, non-toxic, } \\
\text { non-flammable }\end{array}$ & $\begin{array}{l}\text { High investment; high } \\
\text { maintenance costs }\end{array}$ \\
\hline $\begin{array}{l}\text { Ultrasound assisted } \\
\text { extraction }\end{array}$ & $\begin{array}{l}\text { In combination } \\
\text { with steam or } \\
\text { organic solvents }\end{array}$ & $\begin{array}{l}\text { Integrity of EO's; Lower } \\
\text { investment (compared to } \\
\text { SCFE) }\end{array}$ & $\begin{array}{l}\text { Small scale equipment; } \\
\text { Focus on specific } \\
\text { ingredients of interest }\end{array}$ \\
\hline $\begin{array}{l}\text { Microwave assisted } \\
\text { extraction }\end{array}$ & $\begin{array}{l}\text { Possibilities: } \\
\text { Solvent free; with } \\
\text { steam; with water }\end{array}$ & $\begin{array}{l}\text { Short process time; Better } \\
\text { sensorial properties }\end{array}$ & $\begin{array}{c}\text { Relatively smaller scale } \\
\text { plants; subject of future } \\
\text { developments. }\end{array}$ \\
\hline
\end{tabular}

As said, the massive part of the global volume is extracted via steam distillation [4], due to simplicity and relatively lower investments, justifying the focus of this paper. 


\subsection{Essential Oil Market}

According to the market research company marketsandmarkets [5], the overall plant extract market was US\$ 23.7 billion in 2019 expecting to reach US\$ 59.4 billion by 2025 . The essential oils, part of this value, are mentioned by alliedmarketsearch [6]: US\$ 8 billion in 2018 reaching approximately US\$16-17 billion by 2026 .

\subsection{EO Business Environment}

The essential oil industry operates in an increasingly prominent market [5]. Consumer's behavior has been motivated by the desire for natural products and a heathier lifestyle [5]. Whenever possible or available users are preferring certified organic agricultural products despite the higher prices and difficulty to find them [7].

Even under these important customer requirements, the essential oil industry operates without significant process updates and lacks the application of updated technology [8]. A considerable part of the producers are small farmers, without frank access to either technologic know-how or financial availability [8].

Even the major manufacturers, those more professionally established, present clear opportunities to improve their operations in a more structured way, in terms of technology, meaning a gap to be filled towards business excellence.

Under the pandemic scenario, the projections for the essential oil market are still positive as reflected in the market research sites $[5,6]$

\section{4. $\mathrm{KPI}-$ Proposal of a minimum list for EO operations}

It is recommended, as good managerial practices, to set a KPI's list: EO industry is not an exception. KPI management has already been addressed extensively, however, their importance must emphasize the importance as a driver for improvements in essential oil segment, both for establishing objectives as for tracking performance through them [9].

EO operations management, consists ultimately of the quest for efficiency improvements. As a minimum operational KPI list, it is presented the following parameters: yield, OEE* (Overall Equipment Effectiveness), quality (analytic), batch time and energy efficiency [10]. In parallel, the capacity management is a strategic pillar to assure supply chain is capable to respond to sales requirements, on time and in full.

*OEE is defined as the product of 3 factors, according to equation (1):

$$
\text { OEE }=\text { Availability } x \text { Performance } \times \text { Quality }
$$

\subsection{TDC (Total Delivered Cost) and TDC Optimization}

The Total Delivered Cost is an important KPI composed by four cost components: Raw Materials (RM); Packaging Materials (PM); Manufacturing Expenses (ME) and Logistics (L), as shown in the equation (2), below:

$$
T D C=R M+P M+M E+L
$$

TDC optimization comprises a set of efforts to improve company's gross margin results. The word "optimization" is applied instead of "reduction", which could lead to 
the undesired understanding of prioritizing reducing costs in detriment to quality, maintenance practices and customer care requirements [11].

\section{METHODOLOGY}

As methodologic structure, it is shown in Figure 1 the strategic dimension of technology over EO business, in terms of business environment - already addressed above - digital technology \& process control as well as the positive impacts over the gross margin, leading to better KPl's

Figure 1. Technology as Strategic Dimension

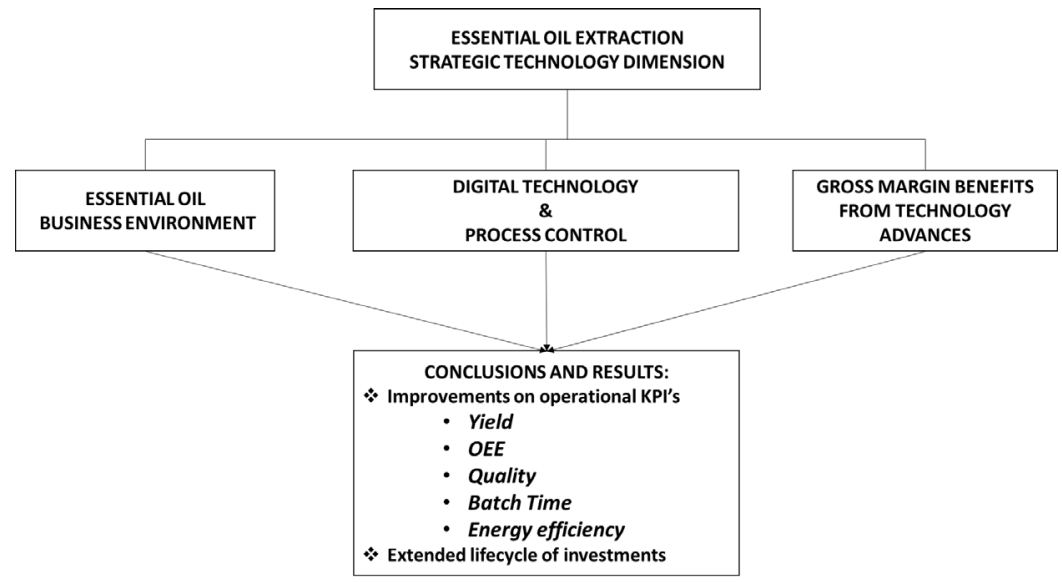

Business owners and managers, when reading the content of this paper, should be compelled to pursue better results through the technology lever. The impacts will be discussed in terms of operational KPI's and their influence on the business overall.

\subsection{Implementation of Technology and Process Control}

Essential oi extraction industries base their processes parameters essentially in previous historic experiences. The design and installation of sensors and control systems are the basic steps to reach a reasonable level of process understanding and control, beyond the usual parameters established only via practice. The process illustrated in Figure 2 is basic, without sensors, as usually in that industry.

Figure 2. Essential Oil Basic process, without sensors and automatic controls

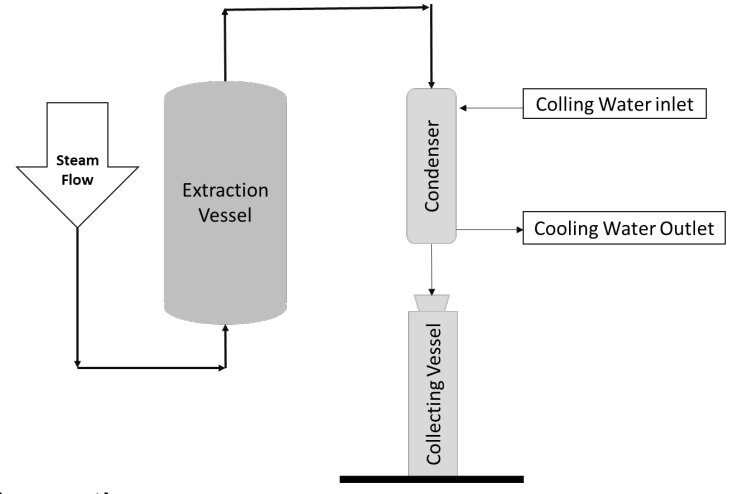

Source: The authors

Figure 3 shows an example of Process and Instrumentation Diagram (P\&ID) (symbology according to ISA) with a simple design proposal for instrumentation. Of course, the complexity level of the improved installation will depend on the expected return on investment and the availability of funds, respecting the principles of economic engineering. 
Figure 3. P\&ID - Example of essential oil extraction process with instrumentation

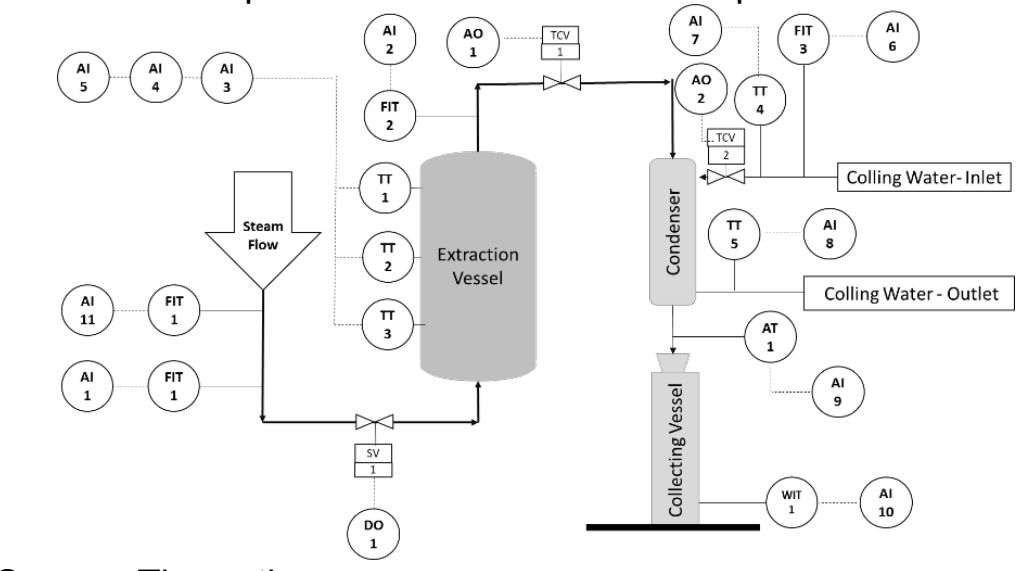

Source: The authors

When sensors are designed to cover process needs, the effective control of parameters levers optimized results. Other important features for control and process management architecture complete that scenario: programmable logic controller (PLC), Supervisory, Control and data Acquisition system (SCADA) and, eventually, other levels of manufacturing management, the Manufacturing Execution System (MES).

\subsubsection{Modeling and Machine Learning Aspects}

When a culture of operation and process control takes place within a company, other levels of process development are considered. For instance, models, allow process simulation and optimization of operational parameters. Just as illustrative element, Figure 4 shows a view of Digital Twin, which is the most advanced model for a real process digital representation, delivering optimized parameters, setpoints, times and self-configuration for next batches, from machine learning principles.

Figure 4. Integration between Real Product and Digital Representation

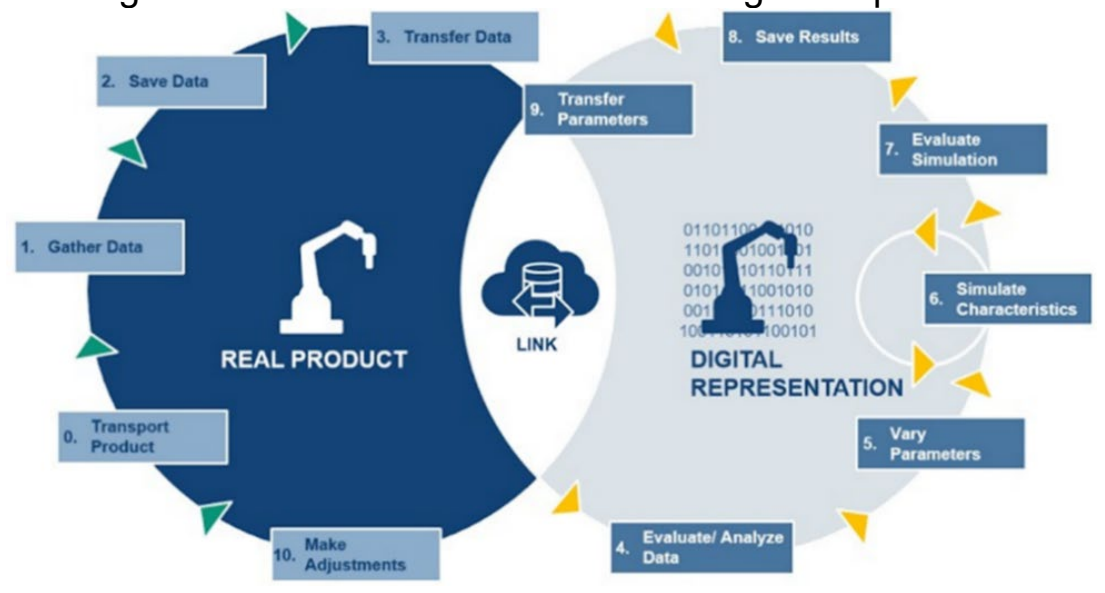

Source: Unity Consulting \& Innovation

\subsubsection{A View of Operational KPI's Improvement}

Investments in technology within EO industry will generate increasingly positive results, reflected in the KPI's (see minimum list in item 1.4.).

Yield: When EO yield of extraction is maximized (improved mass balance), raw materials (RM) factor within TDC will reflect the positive impact on TDC and gross 
margin; OEE: Technology will deliver better effectiveness: increasing availability, performance and reducing losses due to low quality; Quality: Processes will prevent the undesired degradation of EO elements when technology is in place; Batch Time: This KPI is linked to availability and performance (OEE) and closely related to capacity planning and management; Energy efficiency: Optimizes energy per unit produced; TDC: The main indicator in terms of operation management reflecting the bottom line of the overall performance improvements.

Given the importance of TDC, a graphic (Figure 4) demonstrates how TDC optimization improves margin and reduces exposures.

Figure 4. TDC Evolution due to technology enhancement

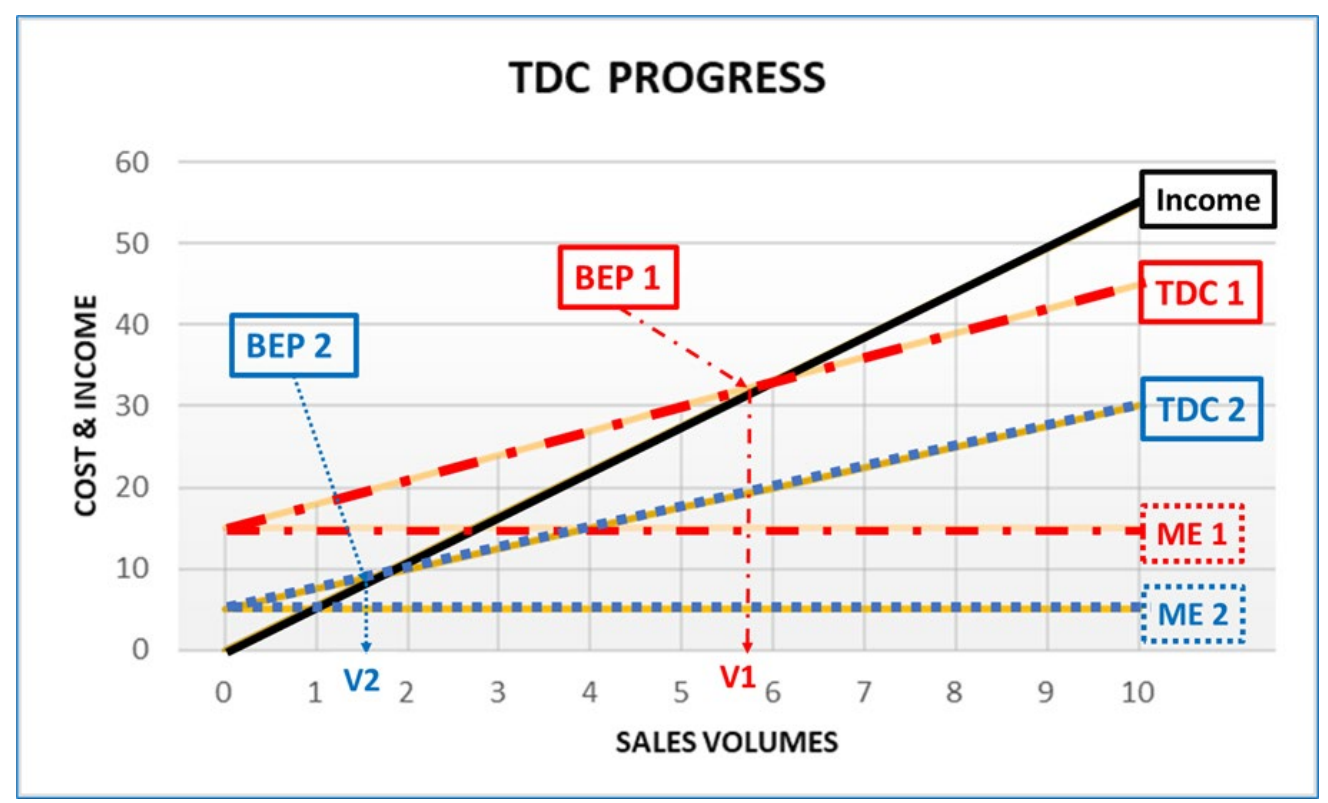

Source: The authors

Income: Total value (cash; revenue) from sales and invoices to customers; TDC: Total Delivered Cost; ME: Manufacturing Expenses; BEP: Break Even Point; V: Volume of sales; Index 1: Before technology updates; Index 2: After technology updates

The indexes 1 reflect the figures before the technology implementation, meaning higher ME and TDC costs. When technology is in place, the indexes 2 show improved ME and TDC, delivering more competitive BEP. BEP2 < BEP 1 (V2 < V1), which means a smaller business exposure.

Note: ME (Manufacturing Expenses) was considered fixed by simplification, without impact on the methodology.

\section{RESULTS AND DISCUSSION}

A hypothetical case was assessed showing a hypothetical case where a company with only one extraction vessel of, for example, $1000 \mathrm{~kg}$ capacity (dry raw material), experiences yield evolution from $1 \%$ to $1.2 \%$ due to technology improvements. For simplification, manufacturing expenses were estimated at $\mathrm{R} \$$ 4.000,00 per employee, all included as well as energy consumption. Table 2 demonstrates figures from the estimates. Reduced manpower requirements and batch time are responsible for an interesting new scenario, called below as "after". 
Table 2. Hypothetical Assumptions - Business Case

\begin{tabular}{|c|c|c|c|}
\hline \multicolumn{4}{|c|}{ OPERATION CONDITIONS } \\
\hline \multirow{2}{*}{\multicolumn{2}{|c|}{\begin{tabular}{|l|} 
Raw Material (RM) \\
Cost of RM \\
\end{tabular}}} & $\mathrm{kg}$ & 1000 \\
\hline & & $\mathrm{R} \$ / \mathrm{kg}$ & $\mathrm{R} \$ \quad 1,00$ \\
\hline \multicolumn{2}{|l|}{ Sale Price of EO } & $\mathrm{R} \$ / \mathrm{kg}$ & $R \$ 150,00$ \\
\hline \multicolumn{2}{|c|}{ Comparison Before - After } & BEFORE & AFTER \\
\hline Yield & $\%(\mathrm{~kg})$ & $1 \%(10)$ & $1,2 \%(12)$ \\
\hline Manpower & people & 3 & 2 \\
\hline Batch Time & $\mathrm{h}$ & 4 & 2 \\
\hline
\end{tabular}

\begin{tabular}{|c|rc|lc|}
\hline \multicolumn{4}{|c|}{ TDC (R\$/kg of extracted essencial oil) } \\
\hline DC Factors & \multicolumn{3}{|c|}{ BEFORE } & \multicolumn{2}{c|}{ AFTER } \\
\hline RM & $\mathrm{R} \$$ & 100,00 & $\mathrm{R} \$$ & 83,33 \\
\hline PM & $\mathrm{R} \$$ & - & $\mathrm{R} \$$ & - \\
\hline ME & $\mathrm{R} \$$ & 225,00 & $\mathrm{R} \$$ & 100,00 \\
\hline $\mathrm{L}$ & $\mathrm{R} \$$ & 10,00 & $\mathrm{R} \$$ & 8,33 \\
\hline TDC & $\mathrm{R} \$$ & 335,00 & $\mathrm{R} \$$ & 191,67 \\
\hline
\end{tabular}

Figure 5 demonstrates technology update impacts over business breakeven point, reducing the company exposure to volume sold and bringing the overall business performance to a more convenient steering and control.

Figure 5. TDC and BEP evolution: comparison between before and after investments

TDC Evolution - BEP Evolution

Before and After Investments in Technology

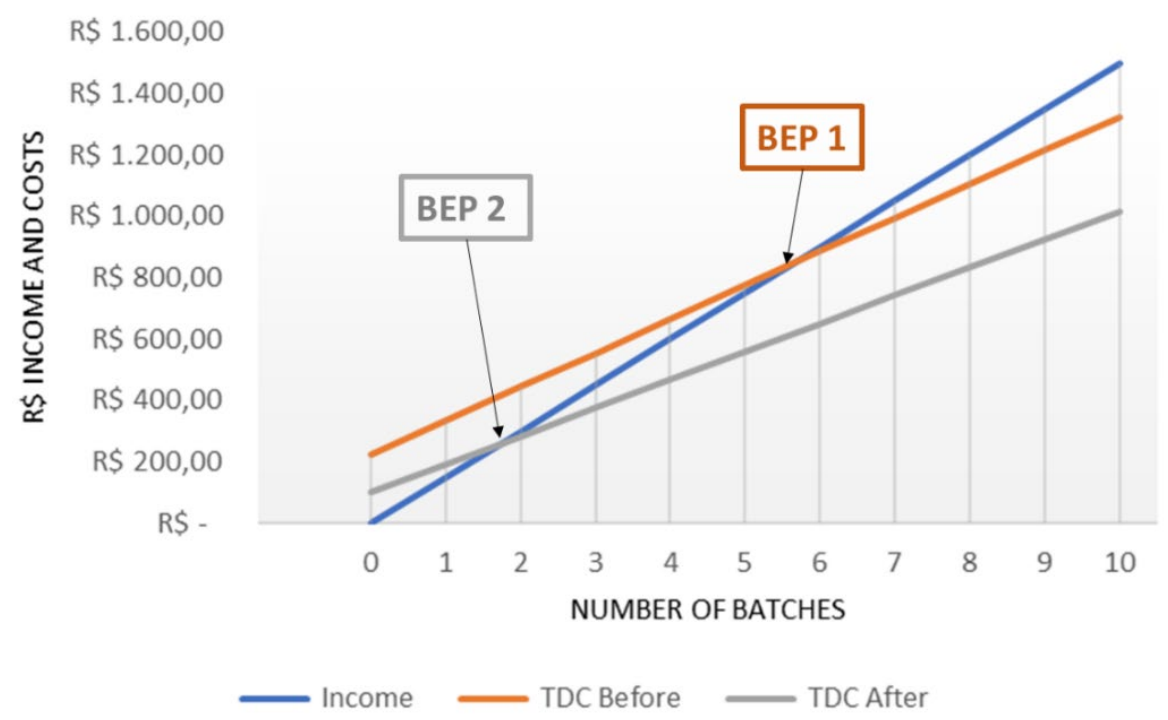

In this hypothetical scenario, a short improvement from $1 \%$ to $1,2 \%$, was evaluated with its beneficial effects on gross margin and overall business performance. The quest for better results will mean the reason to pursue technology enhancements as basis for business perpetuity.

As far as process effectiveness is concerned, this paper was targeted to bring up the discussion over the technology update positive effects on the EO business, arising the motivation to validate this strategic value. It remains, as subject for future works, the application of these propositions to real cases. Such proposals - even though straightforward - are a case for studies and experiments $\mathrm{i}$

\section{CONCLUSION}

A comprehensive program of investments on technology updating is a key factor for business success. When Essential oil industry aims at improving competitiveness, these strategic projects are necessary to assure business perpetuity as well as operational effectiveness, with effects on gross margin, environmental impact and image to customers. 
Several scenarios can be established in function of capital availability, geographic demands and, importantly, competitive requirements. Consuming behaviors are changing dramatically towards green products, services and corporations, indicating a direction for top management and owners to pursue efficiency. Overall business results will no longer stand on only on financial aspects.

\section{Acknowledgments}

Authors are grateful for the financial support from the BAHIA STATE RESEARCH FOUNDATION - FAPESB for the research grant awarded (5633/2019).

\section{REFERENCES}

${ }^{1}$ PREEDY, Victor R. (Ed.). Essential oils in food preservation, flavor and safety. Academic Press, 2015.

2 STRATAKOS, Alexandros Ch; KOIDIS, Anastasios. Methods for extracting essential oils. In: Essential Oils in Food Preservation, Flavor and Safety. Academic Press, 2016. p. 31-38.

${ }^{3}$ EL ASBAHANI, A. et al. Essential oils: from extraction to encapsulation. International journal of pharmaceutics, v. 483, n. 1-2, p. 220-243, 2015.

4 MASANGO, Phineas. Cleaner production of essential oils by steam distillation. Journal of Cleaner Production, v. 13, n. 8, p. 833-839, 2005.

${ }^{5}$ www.marketsandmarkets.com/Market-Reports/plant-extracts-market

${ }^{6}$ www.alliedmarketresearch.com/essential-oils-market

7 CHRISTENSEN, Tove; DENVER, Sigrid; BØYE OLSEN, Søren. Consumer preferences for organic food and for the shares of meat and vegetables in an everyday meal. Journal of International Food \& Agribusiness Marketing, v. 32, n. 3, p. 234-246, 2020.

8 CHÁVEZ, Manuel Guillermo Cerpa. Hidrodestilación de aceites esenciales: modelado y caracterización. 2007. Tese de Doutorado. Universidad de Valladolid.

9 NAKANO, Mikihisa. Roles of the SCM Steering Department. In: Supply Chain Management. Springer, Singapore, 2020. p. 215-233.

10 STEENKAMP, L. P.; HAGEDORN-HANSEN, D.; OOSTHUIZEN, G. A. Visual management system to manage manufacturing resources. Procedia Manufacturing, v. 8, p. 455-462, 2017.

11 BAKOUSSEVA, Renata. Integrated supply and production network design. 2016. Tese de Doutorado. Massachusetts Institute of Technology. 